\title{
Sanctity of Life and Human Dignity as Human Rights Values Vis- À-Vis The Death Penalty: A Religio-Ethico Reflection
}

\author{
Dr. Nico P. Swartz \\ University of Botswana. Faculty of Social Sciences \\ Dept of Law. Private Bag 00705. Gaborone.
}

\begin{abstract}
The paper aims to presents a consistent argument and ideology of life. The study proposes capital punishment as an earthly creation, born out of man's attempt to find justice according to his own standards - in complete opposition to what God's perfection intends. Capital punishment is based on the conviction that man must set the ultimate standard of what is right and what is wrong, and that God's authority is irrelevant to these moral decisions. The paper opted for an exploratory study using literal sources, which the author generated and on which he draws. The article is based on a serious inquiry of original data on the issues of the death penalty, sanctity of life and human dignity. The paper presents a strong, current and relevant theoretical or conceptual framework within which the inquiry is located. The opposition to capital punishment reflects a consistent ethic of life that is evident throughout the Scriptures. The paper finds that sanctity of life and human dignity have become the central argument against the death penalty. It suggests that these two concepts (sanctity of life and human dignity) establish a line that humans or states cannot cross. Every other kind of means which brings human life to a premature end would therefore count as wrong. The research results may lack generalisability in that it focused mainly on a Christian framework. But it can also be viewed as an opportunity for other researchers to test the proposed propositions further, to expand it to the domain of other denominations. But subject to the condition to make this ethic of life that this research holds dear part of their own views.
\end{abstract}

\section{INTRODUCTION}

Both these terms, the "sanctity of life" and "human dignity" have religious, ethical and legal roots. This does not mean, however, that this term may only be used within the confines of these disciplines. The term "sanctity of life" means more than life's freedom from injury. The situation is similar for the term "human dignity," the origins of which lie partly in the Christian idea of imago dei. With regard to human dignity, each human being should be exempted from human interference. From this religious context, the idea of an inherent human dignity becomes part of modern philosophy and law.

There is something within human nature that causes us to appreciate the basic sanctity of individual human life. It is the image of God (imago Dei) that is written on our souls. A general knowledge of God reflects a universal dignity that is present in all people no matter what their actions or environment may be. But there are others who do not accept these truths as axiomatic. Their faith is dependent on those things that they can see or touch or otherwise quantify in the material world. For them, discussions of divine purpose are irrelevant. They frame their discussions of philosophical ethics in arguments that rely exclusively on pragmatic results and material rewards.

Support of the capital punishment ideology is not based on a moral appreciation for life, but rather in new legislative-like principles of individual entitlement. Capital punishment is an 
earthly creation, born out of man's attempt to find justice according to his own standards - in complete opposition to what God's perfection intends. It is based on the conviction that man must set the ultimate standard of what is right and what is wrong, and that God's authority is irrelevant to these moral decisions. We have an unfortunate habit of placing our worldly concerns of politics and economics ahead of our spiritual concerns of faith and morals. Some current judicial systems do not even pretend to follow these standards. If capital punishment is to be allowed, this research emphasizes, we would see the end of a system of justice based on the rule of natural law. The only way we can avoid this fate is if we present a consistent argument and ideology of life.

The state has a duty to protect "human dignity" and the citizen's "right to life." In other words, it has a duty to "protect the dignity and integrity of all human beings." This view is echoed in articles 2 and 3 of the European Convention for Human Rights and in article 1 of the Bioethics Convention of the Council of Europe.

The concept of "human dignity" has also been used by the Supreme Court of the United States in connection with the Eight and Fourteenth Amendments. Human rights are anchored in the "inherent dignity" of the human being. Bayertz asserts that the protection of human life is one of the highest priorities of a modern state.

\section{CAPITAL PUNISHMENT? AN ANACHRONISTIC CONCEPT}

Capital punishment was tolerated as a necessary tool for an archaic age that was still blind to consequences of a society based on force. Yet, it must never be viewed as a permanent solution to the problem of violent crime.

The 12th century judge was limited in his options of punishment. Without sophisticated prison systems or reliable judicial apparatus, there was no conceivable solution to the problem of repeated offenders.

There were no police networks to actively protect against marauding bands of outlaws, nor was there a prison system set up to ensure the safe isolation of dangerous individuals. Oftentimes, the options were death, maiming, exile or freedom. A prison sentence might be interpreted as a temporary delay of escape. If the criminal was not killed, he very well may threaten the well-being of society, especially if his crimes are violent by nature.

Fortunately, these conditions simply do not exist today. We can protect society without killing its worst offenders. Other nations throughout the world, have completely outlawed capital punishment with no serious consequences. Capital punishment is no longer a utopian expectation.

Today, we have the means and opportunity to isolate a dangerous criminal in such a way as to never place the society in danger again. Escape is rare and virtually unknown in the highest security prisons. The police network of modern societies is so advanced that even if a criminal does escape, they will have to voluntarily remove themselves from society if they are to avoid recapture. It simply is no longer necessary to kill someone in order to provide society with sufficient protection against direct attacks in the future.

In the twentieth and the twenty-first centuries we believe that each individual is entitled to the basic rights of life and dignity. Governments ought to exist to protect those rights. Our nations 
was founded on the enlightened reasoning of John Locke and others who argued that if government fails to uphold its duty, then the people must seek to alter or abolish it.

In our modern jurisprudence, there is no way that we can find justification for capital punishment. As a result, modern cities of man have come closer toward a sense of justice than ever before. Criminals are housed in secure facilities and whenever possible given the necessary help to bring them into a new and reformed lifestyle. This research stresses that on the strength of these facts is that if criminals and offenders can be dealt within means short of execution, we must seek to do so. The message this paper would want the global community to know, is, to demand the criminal's life when his removal from society is sufficient reflects an earthly pursuit of vengeance. As Christians (and other denominations), we must resist this temptation.

\section{USURPATION OF GOD'S AUTHORITY BY THE ARROGANT HUMAN BEING}

The root of man's sin stems from his desire to assume God's authority. Man always falls astray when he begins to place himself in a role of judgment meant for God. However, man must never assume authority over that which he does not know. When he takes away a man's life from his physical body, he is clearly over-stepping his bounds of authority. The stamp of God is found in our souls (imago Dei). The Scriptures tell us that we have been created in the image of God. Therefore our lives are claimed by God alone, and no man has authority over them. Capital punishment denies the redemption of Christ by requiring material punishments based on our own judgment. Capital punishment is therefore contrary to Christian faith and other faiths that uphold an ethic of life.

When confronted with issues such as capital punishment, Christians tempted to fall into a purely empirical discussion. They would prefer arguments that are more reasonable and pragmatic, than those that are strictly religious. This problem comes in two flavors: those who ignore their sources of faith altogether, and those who use material definitions to interpret their sources of faith in the way that best suits their needs.

Those in the first grouping make their arguments in favor of capital punishment based on crime statistics, economic issues and a basic need to guarantee the authority of the state as the sole executor of justice. This group prefers to fall back on an argument that supports the separation of church and state. Then they follow up with a distinction between moral issues and political issues, each with their respective domain - that capital punishment is relegated to the political domain, and therefore should not be approached by articles of faith. We must recognize that there is a clear distinction between spiritual matters and worldly matters, but the gist of this paper exerts that we must remember that divine truth transcends all.

We find that capital punishment is not only contrary to Biblical principles and Judeo-Christian theology, but it also defies any reasonable argument based on faith in a single loving God.

In the Papal Encyclical, Donum Vitae (1987), it is written: "The inviolability of the innocent human being's right to life from the moment of conception until death is a sign and requirement of the very inviolability of the person to whom the creator has given the gift of Life," and subsequently, "Human life is sacred... God alone is Lord of life from its beginning until its end: no one can, in any circumstances, claims for himself the right to destroy [a human being]." In destroying human life, the document states: "By acting in this way the [state] usurps the place of God; and, even though [the state] may be unaware of this, [it] sets [itself] up as the master of the destiny of [human beings] inasmuch as [it] arbitrarily chooses whom [it] will allow to live and whom [it] will send to death [...]" 
Keenan upholds that killing is forbidden in that it usurps a divine prerogative and violates divine rights. In simpler terms, "nobody can ever bestow the right to kill [another person]. This would amount to a violation of a divine law, an offence of the dignity of man, and an attack against the human race." This is so, because life is God's gift to man.

\section{The abrogation of capital punishment: An ethic of life acceptance}

Our Lord specifically rebuked the standard of "eye for an eye." When our neighbor strikes us, Jesus asked that we turn the other cheek and let him strike that as well. He told us to love our enemies, and to pray for those who persecute us. In fact, the only specific reference Jesus ever made to capital punishment was a negative one. When the men brought forth the adulterous woman, He said, "[Let] him who is without sin, cast the first stone of her death." If we choose to ignore these sources of inspiration, then it is, quite likely that we are not really interested in the truth at all. Instead, we might be using the material rules of the Scriptures to satisfy our personal opinion - to justify our own personal agendas. The opposition to capital punishment reflects a consistent ethic of life that is evident throughout the Scriptures.

\section{"SANCTITY OF LIFE"}

The principle that human life is holy and inviolable is an argument which runs through religion and ethical debates from Ancient Times to the present day. Since then, the "holiness of human life" has become the central argument against the death penalty.

There is something within human nature that causes us to appreciate the basic sanctity of individual human life. As mentioned earlier in the paper, it is the image of God (imago Dei) that is written in our souls. On the strength of this notion, the "sanctity of life" informs us that we as humans cannot violate a life. The sacred quality of life establishes a line that humans or states cannot cross. God alone, the author of life, has absolute dominion over it.

If one does not want to refer to the authority of the Bible, one may interpret the principle of the "sanctity of life" more mundanely as the principle of the absolute value of human life as per the gist of this research. According to this principle (sanctity of life) every other kind of bringing human life to a premature end would count as wrong.

Keenan allows Aquinas's inquiries into the liceity of Abraham's intention to kill his son and answers, "God is Lord of death and life, for by His decree both the sinful and the righteous die. Hence who at God's command kills a man does not sin, as neither does God whose behest he executes."

"Sanctity of life" requires us to uphold life. The maxim neminem laedere (do no harm) forbids us to "do to others what we do not want to be done to ourselves." The idea behind this maxim is better articulated by saying that we should never do to others what they do not want to be done to them.

The "sanctity of life" principle holds that every life is of equal value regardless of condition.

\section{What is human dignity?}

\section{HUMAN DIGNITY}

Human dignity can be connected with legal personality and legal right. It plays a central role in the contemporary law of human rights. The 20th century law of human rights gives human 
dignity place of pride. Luban makes mention of the preamble to the UN Charter's, which states: "[Faith] [...] [is] the dignity and worth of the human person..."

Article 1 of the Universal Declaration of Human Rights begins, "[All] human beings are free and equal in dignity and rights." The Charter of Fundamental Rights of the European Union begins with Article 1 entitled "Human Dignity" that reads simply, "Human dignity is inviolable. It must be respected and protected." Principle VII of the Helsinki Accords asserts a philosophical proposition that all human rights initiatives derive from the inherent dignity of the human person."

In the U.S., the concept of human dignity is not part of the Constitution, but it has nevertheless been used by the Supreme Court in connection with the First, Fourth, Sixth, Eight and Fourteenth amendments. Within the Preamble of the Universal Declaration of Human Rights of the United Nations on 10 December 1948, recognition of the "inherent dignity" of all human beings is characterized as the basis of freedom, justice and world peace". Art. 1 of the Declaration states: "All human beings are born free, equal in dignity and human rights. They are endowed with reason and conscience and should act towards one another in a spirit of brotherhood."

Human dignity identifies with autonomy, which is an offshoot for the freedom of choice, while paternalism lies in the violation of autonomy. Honoring human dignity means refraining from overriding those commitments for paternalistic reasons (by the state). Having human dignity means being an individual self who is not entirely subsumed into larger communities. Honoring human dignity requires not humiliating people, because humiliation is an affront to my dignity.

Dignity goes with rank. Indignity occurs when someone is treated below their rank. To violate someone's human dignity means to treat them as if they were a being of lower rank, as an animal, as a handy but disposable tool, as property, as an object, as a subhuman or as nothing at all.

\section{Significance of human dignity: Christian grounding of human dignity}

The concept of human dignity did not emerge as a creatio ex nihilo. It is rooted in Ancient philosophy as well as in Christian theology. Christianity interpreted the dignity of all human beings theologically. The latter's origins may be attributed to the special position which the human being assumes within creation as imago Dei. Human dignity is viewed in this research as a reflection of the dignity of God.

The question of the reflection of the dignity of God, is buttressed by an understanding of the person before we can ponder what he/she deserves as a person. Rawls, for example, affirms that you and I as human beings derive our value from social institutions and not from our ontological status as human beings. This is, under the tenor of this research, rather a blatant instrumentalist view of people. In the thought of Rawls, humans are no longer seen as valuable and worthy by government and social structures. Inasmuch as Rawls's theory is moving in this direction, he is impinging on the value and dignity of the human individual. Rawls' approach does not present us with a satisfying picture of the person or human dignity and so cannot compel allegiance with this research.

The aura of significance attaching to human beings is recognized through, for example, the covering of dead bodies with a sheet, certain funeral rituals, and the occasional respect accorded the site of a loved one or venerated figure's death. The realization of the sui generis 
importance of human life was exemplified in the burial service arranged for two newborn infants who separately washed up on the shore of Orange County, California, beaches in March 1995. The newborn infants had been abandoned just hours after their births and were thrown into the ocean. Father Patrick Callahan of St Matthew American Catholic Church in California, Orange County, arranged the service. Explaining why he did so, he said, "I really feel it would be unfortunate for these children to be just cremated and placed in a common grave as if they never existed... There should be some awareness that they were here, even though they only lived for a brief period of time, maybe only a matter of hours... I think [the memorial service] is the respectful thing to do. It celebrates the dignity of children."

This is a deed that demands not only condemnation, but damnation in the full religious meaning of the word. Although the deed is so vile, so heinous, and so essentially evil, the perpetrator (and the victim(s) of crime) possessed human dignity. Every human self is perhaps composed of an intrinsic human dignity and worth. The awareness of human dignity is similar to the innate human knowledge and experience of a Creator.

It is also true that mankind is able to break through the knowledge of universal dignity and mistreat his fellows. Human dignity, disrespected by custom, is easily trampled under the ruthless wheels of bigotry, pride, violence and selfishness. Human individuals can be blatantly used as mere means for utilitarian ends as seen within the context of Rawls' exposition.

Man's dominion is not a license to exploit creation (other human beings) but rather a charge to rule as God would rule. All life, since it comes from God, has a sacredness about it and demands respect for it. The special dignity and sanctity of human life comes from bearing the image of God and the responsibility to rule like God. On the basis of this principle, human rights have to be claimed and defended.

The death penalty is the most profound assault on human dignity. In the absence of a solid and stable understanding of the sui generis and inviolable value of every human being, abuses of human life are a very likely.

The religio-ethico philosophy this research wants to bring forth is that the abiding belief in God humanizes us. By focusing on God, we will become more concerned about people. By recognizing God, we come to a greater valuation of earthly relationships by understanding them as a sacred gift to be cherished. The general Christian grounding of human dignity is summarized as follows: "It is because God has assigned worth to man and woman that human dignity is established." It is because mankind bears the image of God (imago Dei) that he enjoys such an exalted rank in the nature of things. From his creation to his redemption, man's dignity is preserved. Human dignity articulated in this religiously way can serve as an ordering concept for contemporary and social life. The fact that it currently does not function as a civil unifying theory is not itself sufficient ground for deeming the Christian architectonic of human dignity and sanctity of life anachronistic.

\section{RESPECT FOR HUMAN DIGNITY BY THE STATE}

"Regard for dignity implies respect for every individual's right to life..." Respect for human dignity reflects the role of the state and the legal system. The questions that can be asked in this regard are, should the state guarantees the inviolability of human dignity? and should it (the state) serves as an advocate and guardian of the sanctity of life? 
The notion is that the state is to remain morally neutral and to protect the individual's freedom of choice. It is the duty of the state to secure the peace for its citizens, and not to assert a mandatory ideology. All action and legislation of the state is subjected to the principle of the inviolability of human dignity and it must therefore refrains from action infringing on human dignity. No one must tolerate violation of his/her dignity by another or being subjected to the discretion and whims of another without the right of legal contestation. A human being, as person, has legally guaranteed rights and can demand of the state that it deter infringement upon his/her dignity. The positive guarantee of human dignity requires a corresponding order of government. If all the organs of state are obliged to respect and protect human dignity, then the state can fulfill his obligation which is founded upon democratic and social welfare principles. The principles of a state founded upon respect for the law, social welfare and democracy can be derived from the fundamental norm of human dignity and the sanctity of life. Only a state based on respect for the law can guarantee its citizens legal protection. The deterrence of humanly degrading affliction can only be expected from a state which acknowledges its responsibility to take precautionary measures to ensure the welfare of its citizens.

Human dignity cannot be limited. Even prisoners, the legally incapacitated or those incapable of making decisions do not forfeit their human dignity and have the right to be recognized as persons. The appeal to human dignity sets out certain limits. When human dignity is infringed upon, these limits are overstepped. The death penalty is therefore incompatible with human dignity and the sanctity of life. Human dignity as a reference point sets limits to arbitrary behavior. If a human being is not recognized as a bearer of rights, then his inalienable dignity will in no way either be recognized or respected. The recognition of human dignity is to be understood both as a fundamental moral norm and as a legally guaranteed fundamental right. It is the responsibility of the state to protect human rights.

The dignity of man is inviolable. All the powers of state must respect and protect it. Constitutional control over the powers of the state should result from respect for human dignity and sanctity of life. The Constitution must be utilized in order to make the protection of the individual the basis for the state's action. The state is therefore obliged to recognize and protect the individual.

Respect for human dignity demand legal protection of an individual's right to life. A state which refuses to enforce this demand has lost the right to Christian morals. Protecting human dignity is essential for the legitimatization of state power. Respect for human dignity serves as an orientation point and a critical norm insofar as it provides fundamental orientation and lends purpose to moral and legal debate.

\section{SENTIMENTS AGAINST THE DEATH PENALTY}

Justice Chaskalson, had found in the Constitutional Court case of South Africa, S v Makwanyane 1995 (3) SA 391 (CC), that there was no proof that the death sentence was a greater deterrent than imprisonment. He quoted police statistics that in the previous five years on average 20,000 murders were committed and out of the 9,000 murder cases brought to trial only 243 death sentences were imposed with 143 of these being confirmed on question: Would the carrying out of the death sentence on these 143 persons have deterred the other murderers or saved any lives? Similarly in Nigeria studies on murder and armed robbery have demonstrated that the death penalty does not act as a deterrent. The deterrent effect of the death sentence thus remains questionable. 
Given the vast majority of persons charged with capital offences, many will not be able to afford the services of advocates. In the interest of justice an accused person should be entitled to be represented by an advocate at public expense. The question that can be posed, is whether such a person would receive satisfactory representation. Evidence suggests that in general, advocates taking on "pauper briefs" are noted neither for their caliber nor for their commitment. Hatchard \& Coldham buttress this notion, when they wrote, "In Tanzania, in a case where the constitutionality of the death penalty was raised, the trial judge pointed out that the risk of executing the innocent is increased by the fact that 'most poor persons do not obtain good legal representation, as they are defended by lawyers on dock briefs who are paid only T Shilings 500 (the equivalent of US \$1)'”

In Nigeria there had been a number of appeals against convictions for murder on the ground that the accused's counsel had failed to discharge his professional duty in a proper manner. The Nigerian Robbery and Firearms Decree of 1984 provides for a special tribunal for the trial of offences of robbery, attempted robbery, etc. The tribunal can impose the death sentence for armed robbery. While the sentence has to be confirmed by the Military Government, there is no provision for appeal to the courts, nor are the tribunals bound by the normal rules of evidence and procedure.

The Malawian Traditional Courts Act of 1969, which was not governed by either the Criminal Procedure Act or the Evidence Act, did not allow lawyers to appear before it. Murder and treason as capital offences were tried before these courts. During certain trial processes none of the defendants called witnesses of their own and many failed to offer any defences other than a simple denial. Defendants had also little idea how to conduct their cases and the courts, instead of assisting them, created rather an intimidating environment. This unfair situation was as a result removed under the new constitution of Malawi.

Discrimination upon the race of the offender and race of the victim seem to be problematic. In the United States of America, black offenders who kill white victims are more likely to be sentenced to death than white offenders who kill black victims under similar circumstances. The death penalty system discriminates on the basis of the sex of the offender, because women are less willing to be subjected to the death penalty than men.

Poverty level of the offender and victim also determines in part the outcome. An offender from a lower economic and social strata who murders a victim from higher economic and social strata, stands the greatest chance of being sentenced to death and actually executed. These and other legally irrelevant factors cause these literally life-and-death decisions to be made in a discriminatory manner.

In, for example, the USA a capital defendant's attorney should be experienced in capital cases and should devote major portions of his time and energy to the case. The particular attorney should be aided and supported by legal assistants, investigators, and other members of a complete defense team. This is the sort of team effort that the prosecuting attorney has, so the defense attorney should have a comparable team. Only rarely does the defense team equal the prosecution team in numbers, experience, and funding. The mismatch between prosecution and defense often results in a denial of a full and fair consideration of the defendant's guilt and sentence. Capital defendants with inadequate defense teams may receive the death penalty, while essentially identical cases result only in a prison sentence, with the only difference being the quality of the defense attorney. 
An often-heard argument, which will be embraced by pro-death sentiments, for executing the offender is that it saves the cost of providing room and board in a maximum security facility for the rest of the offender's life. The total expenditure might well be in the range of a million dollars. The surprising fact is that the death penalty is much more expensive than life imprisonment. The long death penalty process - coupled with the rarity of it ending in actual execution - results in a very high cost-per-execution. Research has shown that the average cost-per-execution is several million dollars, much more than the cost of keeping that executed prisoner in prison for several lifetimes. This is counterintuitive to those who argue that we shouldn't use precious tax dollars to feed and house convicted murderers. Many more of those tax dollars are required to execute the prisoner than would be needed to keep him in prison.

The executing of a person who can show that he is innocent comes perilously close to murder, according to Justice Blackmun in Herrera v Collins 506 U.S. 390, 113 S.Ct. 853, 122 L.Ed.2d 203 (1993): "[We] have executed the innocent nonetheless, either because he could not "show that he is innocent" or because we would not believe him." In a speech in July 2001, Justice O'Connor expressed our worst fears: "If the statistics are any indication, the system may well be allowing some innocent defendants to be executed." Justice Souter expressed this concern in Kansas v Marsh 548 U.S. 163, 126 S.Ct. 2516, 165 L.Ed2d 429 (2006): "The period starting in 1989 has seen repeated exonerations of convicts under death sentences, in numbers never imagined before the development of DNA tests." Any government system operated by imperfect human beings and handling thousands of cases each year is bound to make mistakes. If the mistake was to convict and imprison an innocent person, we can correct and perhaps even compensate him for his years in prison. If we execute an innocent person, however, no form of compensation or correction seems adequate to correct error. Erroneous convictions and the fact that most poor defendants did not receive adequate legal representation, made capital punishment, cruel, inhuman and degrading. Research has revealed that two thirds of death sentences are eventually overturned on appeal. This situation is due to the inadequacy of defence lawyers available for poor and black people. The death penalty system is operated and controlled by human beings who are not immune to human error. As are evident under the case law discussed, innocent people are sentenced to death and, in some cases, they are actually executed. Whether for or against the death penalty, almost no one wants innocent people executed. A system operated by human beings operating under intense political pressures is bound to make mistakes. The overarching issue is how many death penalties for innocent persons are too many?

Hugo Bedau stated that it is assumed that no political candidate in, for example, the United States can hope to run for president, governor, or other high elective office if he or she can successfully be targeted as "soft on crime." The candidate's position on the death penalty has become the litmus test.

\section{CONCLUSION}

In this research Christ's Words find a new and particular echo: "What you do to one of the least of my bretheren, you do unto me." (Note 117). In line with this Biblical phrase, this research finds that all life comes from God and has a sacredness about it and demands respect. Within this notion and with regard to the tenor of the research, the death penalty is to be regarded as the most profound assault on human dignity and sanctity of life. By defending man against the excesses of his own power, this research reminds mankind of the reasons for his true nobility. Only in this way can the possibility of living and loving with that dignity, which derive from respect for the truth be ensured for the men and women of tomorrow. 
With this instruction, this research, in fulfilling its responsibility to promote and defend human rights in so serious a manner, addresses a new and heartfelt invitation to all those who, by reason of their role and their commitment, can exercise a positive influence and ensure that, in society, due respect is accorded to the right to life and human dignity.

This research addresses this invitation to those responsible for the formation of consciences and of public opinion, to jurists and politicians. It hopes that all will understand the incompatibility between recognition of the dignity of the human person and contempt for life, between faith in the living God and the claim to decide arbitrarily the origin and fate of a human being.

\section{Bibliography Books}

Bayertz, K. (Ed.). 1996. Sanctity of Life and Human Dignity. Kluwer Academic Publishers. Dordrecht.

Hodgkinson, P. \& Rutherford, A (Eds). 1996. Capital Punishment. Global issues and Prospects. Waterside Press. Winchester.

Honecker, M. Part Five: The Role of the State. On the Appeal for the Recognition of Human Dignity in Law and Morality. In Bayertz, K. 1996. Sanctity of Life and Human Dignity. Kluwer Academic Publishers, Dordrecht, Netherlands.

Keenan, James F., S.J. Part One: Sanctity of Life. The Concept of Sanctity of Life and Its Use in Contemporary Bioethical Discussion. In Bayertz, K. 1996. Sanctity of Life and Human Dignity. Kluwer Academic Publishers, Dordrecht, Netherlands.

Lenzen, W. Part One: Sanctity of Life. Value of Life vs Sanctity of Life - Outlines of a Bioethics that Does without the Concept of Menschenwürde. In Bayertz, K. 1996. Sanctity of Life and Human Dignity. Kluwer Academic Publishers, Dordrecht, Netherlands.

Luban, D. 2007. Legal Ethics and Human Dignity. Cambridge Studies in Philosophy and Law. Cambridge University Press. Cambridge.

Stetson, B. 1995. Human Dignity and Contemporary Liberalism. Westport Connecticut, Praeger. Greenwood Publishing Group. United States of America.

Streib, V. 2008. Death Penalty in a Nutshell. Third Edition. West. A Thompson Business. United States of America.

Zorea, A. W. 2000. In the Image of God. A Christian Response to Capital Punishment. University Press of America, Inc. Lanham, Maryland.

\section{ARTICLES}

Hatchard, J. (1994). Capital Punishment in Southern Africa: Some Recent Developments. The International and Comparative Law Quarterly, 43(4), 923-934. Doi: 10.1093/iclqaj/43.3.493.

Hood, R. (2001). Capital Punishment. A Global Perspective. Punishment and Society, 3(3), 331-354. Doi: $10.1177 / 1462474501003003001$.

\section{International Conventions And Protocol Instruments}

Bioethics Convention of the Council of Europe.

European Convention for Human Rights.

Principle VII of the Helsinki Accords.

The Charter of Fundamental Rights of the European Union.

Universal Declaration of Human Rights (1948).

CASE LAW

Herrera v Collins 506 US 390, 113 S.Ct. 853, 122 L.Ed 2d 203 (1993).

Kansas v Marsh 584 US 163, 126 S.Ct. 2516, 165 L.Ed 2d 429 (2006).

S v Makwanyane 1995 (3) SA 391 (CC). 


\section{STATUTES}

The Malawian Traditional Courts Act of 1969.

The Nigerian Robbery and Firearms Decree of 1984.

\section{Notes}

Note 91. Streib Death Penalty in a Nutshell (2008) 39.

Note 92. Streib Death Penalty in a Nutshell (2008) 41.

Note 93. Streib Death Penalty in a Nutshell (2008) 67.

Note 94. Donald H. Wallace and Jonathan R. Sorensen. Comparative Proportionality Review: A Nationwide Examination of Reversed Death Sentences. American Journal of Criminal Justice. Vol. 22, no. 1, 1997: 13-40: 13.

Note 95. Streib Death Penalty in a Nutshell (2008) 44.

Note 96. Streib Death Penalty in a Nutshell (2008) 44.

Note 97. Streib Death Penalty in a Nutshell (2008) 44.

Note 97. Short Indiana Journal of Global Legal Studies (1999) 739.

Note 98. Streib Death Penalty in a Nutshell (1999) 293.

Note 99. Short Indiana Journal of Global Legal Studies (1999) 738.

Note 100. Streib Death Penalty in a Nutshell (2008) 294.

Note 101. Streib Death Penalty in a Nutshell 92008) 294-5.

Note 102. Hatchard \& Coldham, chapter 7. Hodgkinson \& Rutherford Capital Punishment . Global Issues and Prospects (1996) 162.

Note 103. Hatchard \& Coldham, chapter 7. Hodgkinson \& Rutherford Capital Punishment (1996) 164.

Note 104. Hatchard \& Coldham, chapter 7. Hodgkinson \& Rutherford Capital Punishment (1996) 164.

Note 105. Hatchard \& Coldham, chapter 7. Hodgkinson \& Rutherford Capital Punishment (1996) 165.

Note 106. Hatchard \& Coldham, chapter 7. Hodgkinson \& Rutherford Capital Punishment (1996) 165.

Note 107. Streib Death Penalty in a Nutshell (2008) 18-9. The Black Codes of the South imposed death sentences for many more crimes by blacks than by whites. In the early 19th century, Virginia law authorized the death penalty for black slaves committing any of about 70 crimes, but had only five death penalty crimes for whites. Georgia required the death penalty for a black male who raped or attempted to rape a white female, but a white male who raped a black female was punished by only a fine and/ or imprisonment. The race of the offender and the victim continued to be important determinants of who did and did not get the death penalty.

Note 108. Streib Death Penalty in a Nutshell (2008) 19.

Note 109. Streib Death Penalty in a Nutshell (2008) 19.

Note 110. Streib Death Penalty in a Nutshell (2008) 21.

Note 111. Streib Death Penalty in a Nutshell (2008) 24.

Note 112. Streib Death Penalty in a Nutshell (2008) 261-2.

Note 113. Hatchard \& Coldham, chapter 7. Hodgkinson \& Rutheford Capital Punishment (1996) 172.

Note 114. Hood Punishment and Society (2001) 344.

Note 115. Streib Death Penalty in a Nutshell (2008) 21.

Note 116. Hood Punishment and Society (2001) 343.

Note 117. Matt 25: 40. 